\title{
The $\mathbb{W H O}$ atlas on global resources for persons with intellectual disabilities: a right to health perspective
}

\author{
Jocelin Lecomte LLB, MA, ${ }^{(1,2)}$ Céline Mercier, PhD. ${ }^{(1,2,3)}$
}

\begin{abstract}
Lecomte J, Mercier C.
The WHO atlas on global resources for persons with intellectual disabilities: a right to health perspective. Salud Publica Mex 2008;50 suppl 2:SI60-SI66.
\end{abstract}

\begin{abstract}
This paper focuses on the links between the WHO atlas on global resources for persons with intellectual disabilities (Atlas-ID) project and the right to health in international human rights law. The WHO Atlas-ID project initiated by the Department of Mental Health and Substance Abuse of the WHO was designed to collect, compile and disseminate data on intellectual disabilities services and resources throughout the world. The right to health, as linked to all other human rights, brings a set of globally agreed upon norms and standards, and out of these norms arise governmental obligations. Even in countries which have a relatively high standard of living, persons with intellectual disabilities are very often denied the opportunity to enjoy the full range of economic, social and cultural rights. This paper aims at establishing the WHO Atlas-ID and the international human rights instruments as two parts of a holistic approach in regards to State provided services to persons with intellectual disabilities and their families.
\end{abstract}

Key words: intellectual disabilities; right to health; human rights; WHO Atlas; resources; services; global survey
Lecomte J, Mercier C.

El atlas de recursos para las personas con discapacidad intelectual de la OMS: una visión desde el derecho a la salud. Salud Publica Mex 2008;50 supl 2:SI60-SI66.

\section{Resumen}

Este artículo se centra en la relación entre el proyecto Atlas-DI de la OMS y el derecho a la salud en la normativa internacional de derechos humanos. El proyecto Atlas-DI de la OMS, puesto en marcha por el Departamento de Salud Mental y Abuso de Sustancias de la OMS, se diseñó para recolectar, compilar y divulgar datos sobre servicios y recursos para la discapacidad intelectual alrededor del mundo. El derecho a la salud, en su relación con todos los demás derechos humanos, engloba un conjunto de normas y estándares aprobados internacionalmente, y de éstos emanan obligaciones gubernamentales. Incluso en países con estándares relativamente altos de vida, a las personas con discapacidades intelectuales se les niega frecuentemente la oportunidad de disfrutar el espectro total de derechos económicos, sociales y culturales. El objetivo de este artículo es el de establecer el Atlas-DI de la OMS y los instrumentos internacionales en derechos humanos como partes integrantes de un enfoque holístico sobre los servicios provistos por el Estado para las personas con discapacidades intelectuales y sus familias.

Palabras clave: discapacidades intelectuales; derecho a la salud; derechos humanos; Atlas OMS; recursos; servicios; encuesta mundial

(I) Lisette-Dupras, Gabrielle-Major and West-Montreal Readaptation Centers, Canada.

(2) Montreal WHO Collaborating Centre for Research and Reference in Mental Health at the Douglas Hospital Research Center, Canada.

(3) Department of Social and Preventive Medecine, University of Montreal, Canada.

Accepted on: December 5, 2007

Address reprint requests to: Jocelin Lecomte.Centre de Réadaptation Lisette-Dupras and West-Montreal Readaptation Center, 8000 Notre-Dame,Lachine (Québec),H8R IH2 Canada.

E-mail: jlecomte.crld@ssss.gouv.qc.ca 
[People with disabilities] frequently live in deplorable conditions, owing to the presence of physical and social barriers which prevent their integration and full participation in the community. As a result, millions of children and adults throughout the world are segregated and deprived of virtually all their rights and lead a wretched, marginal life. ${ }^{1}$

$\mathrm{I}_{\mathrm{n}}^{\mathrm{n}}$ $\mathrm{n}$ the last decade, the international human rights community has rediscovered economic, social and cultural rights. Most notably, it has started to give attention to the right to health, its normative contents and resulting obligations to States. The right to health is closely related to a number of other human rights, such as the right to education, housing, non-discrimination, equality, participation, protection of arbitrary detention, access to information. The enjoyment of these fundamental human rights contributes toward the realization of the right to health, while the enjoyment of the right to health facilitates the enjoyment of these and other fundamental human rights.*

This paper does not offer a comprehensive view of the right to health. Its purpose is rather to present the recently published WHO Atlas on Global Resources for Persons with Intellectual Disabilities (Atlas-ID) as a close companion to the right to health movement. The aim is to establish the two as part of a holistic approach in regards to resources provided by the States to support persons with intellectual disabilities and their families.

\section{The right to health}

\section{- Universal, indivisible, inter-dependent and inter-related}

The right to health was first recognised in the Constitution of the World Health Organization (WHO) in 1946. It has since been recognized and developed through a plethora of key international and regional human rights instruments, most notably the Universal Declaration of Human Rights ${ }^{\ddagger}$ and the International Covenant on

\footnotetext{
* University of Essex. Working Paper on Right to Health, Network Seminar on Human Rights, Colchester UK, 27-28 Apr 2004; 6.

₹ United Nations, 1948. Universal declaration of human rights. GA Resolution 217A (III), UN GAOR, Resolution 71, UN Document A/810. UN New York. Article 25: "Everyone has the right to a standard of living adequate for the health and well-being of himself and his family, including food, clothing, housing, medical care and necessary social services, and the right to security in the event of sickness and disability".
}

Economic, Social and Cultural Rights* (ICESCR). While the right to health is protected by international law, as is the case in relation to other human rights, treaty provisions that pertain to it do not always give a clear and detailed picture of the norms and obligations that this right entails upon States. As such, General Comments, most notably General Comment 14, adopted by United Nations treaty bodies have been most useful in analyzing the States obligations in relation to the right to health. ${ }^{\ddagger}$

General Comment 14 states that human rights and fundamental freedoms are universal, indivisible, interdependent, inter-related. ${ }^{2}$ The universality of human rights allowed for the World Conference on Human Rights to state in 1993, that "all human rights and fundamental freedoms are universal and thus unreservedly include persons with disabilities". ${ }^{3}$ The Montreal Declaration on Intellectual Disabilities goes even further by stating that for persons with intellectual disabilities "the exercise of the right to health requires full social inclusion, an adequate standard of living, access to inclusive education, access to justly compensated work and access to community services". $\$$

The right to health is not only linked to other human rights, they work together, as whole. ${ }^{4}$ Accordingly, you cannot exercise one while having the other negated. The right to education can be impended by the negation of the right to mobility or, reversely, the right to vote for all can be rendered void by the negation of the right to

\footnotetext{
* International Covenant on Economic, Social and Cultural Rights (ICESCR), 1966. GA Resolution 2200 (XXI), UN GAOR, 21 $1^{\text {st }}$ Session, Supplement No. 16, at 49, UN Document A/6316, UN, New York. Entered into force January 3, 1976. Article 12: "the right of everyone to the enjoyment of the highest attainable standard of physical and mental health". The ICESCR's supervisory body is the Economic, Social and Cultural Rights Committee (CESCR).

₹ General Comments are interpretive statements issued on specific provisions in an attempt to clarify the nature and scope of rights and obligations under ICESCR. While non-binding, General Comments are deemed as having significant legal weight and offering insights into the meaning of the rights enunciated in the ICESCR.

$\S$ On October $5^{\text {th }}$ and $6^{\text {th }}, 2004$, Montreal hosted the Montreal PanAmerican Health Organization \& World Health Organization Conference on Intellectual Disability. The crowning accomplishment of the Conference was the unanimous adoption by its 65 participants, as well as the principal organisations committed to the defence of the rights of persons with intellectual disabilities, of the Montreal Declaration on Intellectual Disabilities. For more details see www. montrealdeclaration.com as well as Lecomte J, Mercier C. The Montreal Declaration on Intellectual Disabilities of 2004: An important first step. Journal of Policy and Practice in Intellectual Disabilities, 2007;4(1):66-69.
} 
education for women, thus restricting alphabetization to males only.*

But although linked to other human rights, it is the right to non-discrimination that constitutes the fundamental element of the right to health. The principle of non-discrimination is not only a core human right but it plays an even larger role in the realm of international law when in interaction with other human rights of a civil, political, economical, social or cultural nature. Health must be affordable to all without discrimination. The International Covenant on Civil and Political Rights $^{\ddagger}$ (ICCPR) and the ICESCR ${ }^{\S}$ create an obligation on States to guarantee that their provisions are exercised without discrimination of any kind, among others, as to disability.

\section{- Responsibilities of the States}

The main legal responsibility for securing the right to health falls upon States. However, the right to health does not signify the right to be healthy. States cannot be asked to guard against every possible cause of ill-health, as an individual's health can be affected by such determinants as genetic factors, individual susceptibility and the adoption of unhealthy lifestyles. ${ }^{5}$ Thus, the right to health must be understood as the right to "the enjoyment of a variety of facilities, goods, services and conditions necessary for the realization of the highest attainable standard of health". ${ }^{5}$

States must therefore respect, protect and fulfil the right to health. Respect signifies respecting the right by way of not directly violating it. Protect signifies protecting the right by outlawing violations of the right by non-State actors. And fulfil means fulfilling the right by making sure that its real exercise is not theoretical. ${ }^{2}$

Violations of the obligation to respect are those State actions, policies or laws that result in (for example) the denial of access to health facilities, goods and services to particular individuals or groups as a result of de

\footnotetext{
* Examples taken from: Lecomte J, Mercier C. The emergence of the human rights of persons with intellectual disabilities in international law: The cases of the Montreal Declaration on Intellectual Disabilities and the United Nations Convention on the Rights of Persons with Disabilities in Challenges to the Human Rights of People with Intellectual Disabilities. Frances Owen, ed. Jessica Kingsley Publishers, London, England; 2007 (in press).

‡ International Covenant on Civil and Political Rights (ICCPR), 1966. GA Resolution 2200 (XXI), UN GAOR, 21rst Session, Supplement No. 16, at 49, UN Document A/6316, UN, New York. Art. 26. Entered into force March 23, 1976. The ICCPR's supervisory body is the Human Rights Committee.

$\S$ While article 2.2 of the International Covenant on Economic, Social and Cultural Rights refers to "other status", General Comment 14 states that "other status" refers to, among others, disability.
}

jure or de facto discrimination. ${ }^{2}$ Both de jure and de facto discrimination against persons with disabilities have a long history and take various forms. ${ }^{6}$ The effects of disability-based discrimination have been particularly severe in the fields of education, employment, housing, transport, cultural life, and access to public places and services. ${ }^{6}$

Violations of the obligation to protect follow from the failure of a State to take all necessary measures to safeguard persons within their jurisdiction from disregards of the right to health by third parties. This category includes such omissions as the failure to discourage the continued observance of harmful traditional medical or cultural practices. ${ }^{2}$

Violations of the obligation to fulfil occur through the failure of States to take all necessary steps to ensure the realization of the right to health. Examples include the failure to adopt or implement a national health policy designed to ensure the right to health for everyone; insufficient expenditure or misallocation of public resources which results in the non-enjoyment of the right to health by individuals or groups, particularly the vulnerable or marginalized; the failure to monitor the realization of the right to health at the national level, for example by identifying right to health indicators and benchmarks; the failure to take measures to reduce the inequitable distribution of health facilities, goods and services. $^{2}$

\section{The WHO atlas-ID and the right to health}

- Project Atlas-ID

The project Atlas-ID emanated from the Department of Mental Health and Substance Abuse of the WHO. It was designed to collect, compile and disseminate data on intellectual disabilities services and resources throughout the world. It was one of a series of Atlas, that have been published in the context of the WHO Atlas Project, ${ }^{*}$ as a part of the mission of the WHO to offer technical support to its member countries in the development of quality health services. Within this framework, the Atlas-ID

\footnotetext{
* The Department of Mental Health and Substance Abuse (MSD) of the World Health Organization (WHO) began in 2000 the global "Project Atlas" aimed at collecting, compiling and disseminating country data on mental health resources across the world. Atlas on country resources and services have been published in the domains of mental health (World Health Organization, 2001a, b, 2005a), neurological disorders (World Health Organization, 2004), child and adolescence mental health (World Health Organization, 2005b), psychiatric training (World Health Organization, 2005c), and epilepsy (World Health Organization, 2005d). These Atlas are available on the WHO website : www.who.int/mental_health/evidence/atlas.
} 
seeks to make available to WHO Member States, as well as the international community, useful information concerning global resources available in relation to intellectual disabilities resources. As such, the operational objectives of the Atlas-ID were to collect data on the intellectual disabilities resources and services in all 193 WHO Member States, as well as Associated Members, and Areas; to compile and calculate the distribution of intellectual disability resources and services across the WHO regions and countries categories of income level; and to use this information as baseline data to advocate for resource development and to monitor reforms regarding resources devoted to persons with ID, to their families and their environment at the national as well as regional and international levels. The results are based on 147 completed questionnaires (143 Member States of WHO, 1 Associate Member and 3 areas or territories) for a response rate of $74.6 \%$ countries, representing $94.6 \%$ of the world population (2007). The Atlas-ID was launched during the Second International Conference on Intellectual Disabilities held in Bangkok, Thailand in November 2007. It is available at the WHO website.

The Atlas-ID project was to allow, by use of key informants emanating mostly from governmental sources, the emergence of a portrait of what States are currently doing to support their people with intellectual disability. The main aspects covered by the Atlas-ID questionnaire, for each country or territory, dealt with 1) Terminology and the diagnosis criteria utilized within the country to identify ID; 2) Basic epidemiological data; 3) Policy, programs and legislation; 4) Financing of services, compensations and benefits available for persons with intellectual disabilities and their families; 5) Services to children, adolescents and adults; 6) Services to the families; 7) Human resources and training; 8) Role of international organizations and of NGOs; and 9) Research. While these categories seem self-explanatory, the one about services to children, adolescents and adults calls for further comments. The Atlas-ID used services to children, adolescents and adults as an umbrella category to encompass services to housing, health, rehabilitation, education, occupation and employment, leisure, transportation, supply of meal/food, assistive technologies, promotion of rights and advocacy, as well as the barriers to access to intellectual disabilities services in a timely manner.

- Relevance of the Atlas-ID for the promotion and the defence of the right to health

Many dimensions of the Atlas-ID questionnaire correspond to State obligations contained in the ICESCR as well as General Comments 14 and 5. ${ }^{*}$ Those dimensions refer to concepts that are linked to the entitlements of the right to health, such as availability, accessibility, acceptability and good quality of national resources and services to persons with intellectual disabilities and their families. While most of these entitlements are of a progressive realization nature, some create immediate obligations for States to guarantee non-discrimination and equal treatment and to take deliberate, concrete and targeted steps towards the full realization of the right to health, especially for marginalized or vulnerable groups of persons such as persons with an intellectual disability, ${ }^{2}$ as well as to adopt a national health strategy and plan of action designed to ensure the right to health for everyone. ${ }^{2}$

The fact that economic, social and cultural rights are of a "progressive realization" nature has unfortunately contributed to their somewhat lacklustre enforcement by member States. The concept of progressive realization is linked to the available resources by the State, not to its priorities or political imperatives. It should be noted that the absence of economic resources in a State does not constitute justification for a violation of the core fundamental rights of persons with an intellectual disability as established by the ICESCR and the General Comment 14. AState which refuses to use its resources to the maximum to ensure that all citizens enjoy the access to health care in a non-discriminatory way would be in violation of Article 12 of the ICESCR.

- Availability, accessibility, acceptability and quality of national resources and services

The right to health is affected by a number of socioeconomical, political and legal factors. Significant determinants of health include poverty, discrimination, availability of affordable health services and medicines, adequate sanitation and access to clean water, budgetary allocations towards the health and other relevant sectors, government policies and national legislative frameworks. ${ }^{2}$ In General Comment 14, the Committee on

\footnotetext{
* Economic, social and cultural rights such as health, self-determination, employment, transportation, rehabilitation and vocational training programs in integrated settings, social security and incomemaintenance schemes, the right to enable persons (when they so wish) to live with their families, the right to an adequate standard of living, the right to be provided with the same level of medical care within the same system as other members of society, the right to education within the general education system (etc.), as well as civil and political rights such as equality, non-discrimination, access, (etc.).
} 
Economic, Social and Cultural Rights proposed to analyze the right to health through the entitlement to available, accessible, acceptable and quality facilities, goods and services associated with health and the underlying determinants of health. ${ }^{2}$ The Atlas-ID will provide information to proceed to such an analysis in relation to the persons with an intellectual disability.

a) Availability: National health facilities, goods and services must be available in adequate numbers. These facilities, goods and services include the underlying determinants of health, such as safe and potable drinking water and adequate facilities, hospitals, clinics and trained medical and professional personnel. The Atlas-ID provides data on the availability, for children, adolescents and adults, of residential, health, rehabilitation services, educational opportunities, occupational and vocational programs, access to leisure, transportation, supply of meal/food, assistive technologies, support for promotion of rights and advocacy, services to families. The AtlasID describes the presence and type of professionals involved with persons with intellectual disabilities, as well the actions undertaken to prevent intellectual disabilities. Moreover, one can learn from the Atlas-ID how many countries have a national policy and/ or a national programme regarding intellectual disabilities, to which WHO regions and to which income categories they belong.

b) Accessibility: National health facilities, goods and services must be accessible economically and geographically, as well as accessible to the population on a non-discriminatory basis. States are not permitted to offer health resources in a way which unfairly disadvantages people on the basis of, among others, culture or disability. Accessibility has four overlapping dimensions: non-discrimination, physical accessibility, economic accessibility and information accessibility.

(i) Non-discrimination: Health facilities, goods and services must be accessible to all, especially the most vulnerable or marginalized sections of the population, in law and in fact, without discrimination. In the Atlas-ID, data is reported on the presence of a legislation or judicial measures to protect human rights of persons with intellectual disabilities and to fight discrimination.

(ii) Physical accessibility: Health facilities, goods and services must be within safe physical reach for all nationals, especially vulnerable or marginalized groups. Accessibility also implies that medical services and underlying determinants of health are within safe physical reach, including in rural areas. One can find in the Atlas-ID information regarding to what extent geographical factors such as urban vs rural settings and location on the territory represent a barrier to access to services.

(iii) Economic accessibility (affordability): Health facilities, goods and services must be affordable for all. Financing for health-care services has to ensure that these services, whether privately or publicly provided, are affordable for all. States have a special obligation to provide those who do not have sufficient means with the necessary health insurance and health-care facilities, and to prevent any discrimination on the basis of, among others, disability. Inappropriate health resource allocation can lead to discrimination that may not be overt. ${ }^{2}$ In relation with economic accessibility, Atlas-ID data is provided on the impact of socio-economical factors on access to services. Of special interest are the results related to the presence and nature of government benefits for adults and children (or their families) with intellectual disabilities in the participating countries and to the proportion of the persons and families entitled to these benefits that effectively receive them.

(iv) Information accessibility includes the right to information concerning health issues, including information aimed at dispelling prejudices or superstitious beliefs against persons with disabilities. ${ }^{6}$ Data from the Atlas-ID on national epidemiological information, data collection systems, database on services provision and delivery, national reports and documentation about intellectual disabilities falls in this category, as well as results about the presence of intellectual disabilities public awareness campaigns.

c) Acceptability: National health facilities, goods and services must be respectful of the culture of individuals, minorities, peoples and communities. Barriers to access to services related to ethnicity and religions have been documented in the Atlas-ID.

d) Quality: National health facilities, goods and services must be scientifically and medically appropriate and of good quality. This entitlement requires, among others, appropriate training for professionals. The issue of training (pre-graduate, graduate, in-service) of professionals involved in working with persons with intellectual disabilities is covered in the Atlas-ID. Data has also been col- 
lected on the existence of standards of care and practice for professionals and on the ways they are maintained. The presence of research activities in countries has also been documented.

The right to health includes the provision of equal and timely access to basic preventive, curative, rehabilitative health services and health education, preferably at community level. A further important aspect of this right is the participation of the population in the provision of preventive and curative health services, such as the organization of the health sector, the insurance system and, in particular, participation in political decisions relating to the right to health taken at both the community and national levels. ${ }^{2}$ In the Atlas-ID, one can find in the "Ways Forward" section, considerations that echo these fundamental issues about the right to health. This section pinpoints the urgent need "to organize and support advocacy initiatives at the international and national levels to put intellectual disabilities on the countries agendas at the governmental level and to make the civil society aware of the issue", 7 and to enforce accountability mechanisms. A special emphasis is put on community-based rehabilitation services, capacity-building targeted at primary care workers, acknowledgement on initiatives supported by the milieux. Finally, the last way forward promoted in the Atlas bears on the enforcement of human rights and right to health for persons with intellectual disabilities. The concerns are then "to ensure that the recent attention to human rights translates into policies, programs and actions that will effectively impact on the underlying conditions necessary for health (...)" and that persons with intellectual disability "be actively involved in all these processes ". ${ }^{7}$

\section{Conclusion}

This paper focussed on the links between the WHO Atlas-ID and the right to health in international human rights law. Both the Atlas-ID and the human rights approach to health stress the importance of the underlying determinants of health, as well as health care, by looking beyond the health sector. Both attach great importance to public information and education. Both aim for accountability. However, as the human rights approach is one that is built on normative obligations, the Atlas-ID project takes more of a policy approach, where measuring the presence, or lack, of resources and services for persons with intellectual disability becomes in itself a monitoring and accountability mechanism. In providing data and information about the current situation across
States, the Atlas ID brings a unique contribution to the right to health movement. It represents a powerful tool for informed advocacy and for the involvement of responsible and accountable States. As stated by the UN Special Rapporteur on the Right to Health, "accountability is a powerful human rights tool for improving the health of all".*

The primary objectives of the project were the mapping of intellectual disabilities resources and services in all member states of WHO to raise public and professional awareness of the inadequacies of existing resources and services and to document the large inequities in their distribution at the national and global level. The information was also intended to be useful in planning for enhancement of resources. ${ }^{8}$ Resources include: policies, programs, laws, financials resources, compensations, benefits and services for the persons and their families, human resources, education and training, prevention initiatives, activities of international organisations and NGOs, as well as information systems and research. ${ }^{9}$ These resources are necessary to provide services to persons, adult, children or adolescents, with intellectual disabilities. Some, if not most, of these resources also constitute derivatives of the right to health.

Even in countries which have a relatively high standard of living, persons with intellectual disabilities are very often denied the opportunity to enjoy the full range of economic, social and cultural rights. ${ }^{6}$ The right to health, as linked to all other human rights, brings a set of globally agreed upon norms and standards, and out of these norms arise governmental obligations. The WHO Atlas-ID has tried to shed light on the extent of State commitment to resources and services in intellectual disabilities, thus monitoring State protection, respect and fulfillment of their right to health obligations. As was recently noted, "the systematic collection of data on the human rights of a population would give strong inferences about state-bred oppression and so provide a strong tool to pressure for change". ${ }^{10}$ The UN Committee on Economic, Social and Cultural Rights ${ }^{11}$ has emphasised that it is up to States to decide how they give effect to the rights contained in the ICESCR, including the right to health. While the means chosen to promote the full realization of the economic, social and cultural rights of persons with intellectual disabilities

\footnotetext{
* Hunt P. Public Health and Human Rights: At the crossroads. Speech given at the American Public Health Association Annual Meeting, Boston, USA, $9^{\text {th }}$ November 2006.
} 
will inevitably differ significantly from one country to another, there is no country in which a major policy and programme effort is not required. ${ }^{6}$ The will of the States are and will remain the key variable in this respect.

\section{References}

I. Despouy L. Special Rapporteur, Final Report 3, U.N. Doc. E/C4/ Sub2/I99|/3I;12 Jul 199I.

2. United Nations, 2000. Committee on Economic, Social and Cultural Rights (UNCESCR). General Comment No. 14 (Eleventh Session). The right to the highest attainable standard of health. UN Document E/C.I 2/2000/4. UN, Geneva. No. 30

3. United Nations. Vienna Declaration and Program for Action, World Conference on Human Rights, Vienna, Jun 14-25, 1993, UN Doc A/ CONF.I57/23, II (B) (6) (63).

4. World Health Organization. $25 \mathrm{WHO}$ questions and answers on health and human rights. Health \& Human Rights Publication Series. 2002 Jul. Issue No. I.
5. Essex University. International Federation of Health and Human Rights Organisations and the Human Rights Centre, Our right to the highest attainable standard of health, Colchester UK, 2006. Available from: www2. essex.ac.uk/human_rights_centre.

6. United Nations. Committee on Economic, Social and Cultural Rights (UNCESCR). General Comment No. 5 (Eleventh Session). Persons with Disabilities. UN Document E/C. I2/1994//3. UN, Geneva.

7. World Healtth Organization. Atlas: Global resources for persons with intellectual disabilities (Atlas-ID). Geneva:WHO 2007.

8.Available: http://www.who.int/mental_health/evidence/atlas/en/ [Consulted on August 3 2007].

9. Mercier C, Saxena S, Lecomte J, Garrido-Cumbrera M, Harnois G. The WHO Atlas on country resources for intellectual disabilities: initial steps. Journal of Policy and Practice in Intellectual Disabilities, 2008.

10. Mills E. Health, human rights, and the clash with complacency. Lancet 2006 Dec 9; 368(9552):2045-2046.

II. United Nations. Committee on Economic, Social and Cultural Rights (UNCESCR). General Comment No. 9, The domestic application of the Covenant, UN Document E/C.I2/1998/24. 